\title{
URBANISTINIO PLANAVIMO DEFORMACIJOS
}

\author{
Pranciškus Juškevičius ${ }^{1}$, Kristina Gaučè ${ }^{2}$ \\ ${ }^{1}$ Urbanistikos katedra, Vilniaus Gedimino technikos universitetas, \\ Pylimo g. 26/Traku g. 1, 01132 Vilnius, Lietuva \\ ${ }^{2} U A B$,Statybos strategija“, Smolensko g. 10, 03201 Vilnius, Lietuva \\ Miestu statybos katedra, Vilniaus Gedimino technikos universitetas, \\ Sauletekio al. 11, 10223 Vilnius, Lietuva \\ El.paštas: ${ }^{1}$ pjuskevicius@gmail.com; urbkat@vgtu.lt; ${ }^{2} k r i s t i n a @ s-s t r a t e g i j a . l t ; k r i s t i n a . g a u c e @ v g t u . l t$
}

Iteikta 20100913

\begin{abstract}
Santrauka. Urbanistinès deformacijos yra masinis reiškinys. Straipsnio autorių tikslas - remiantis teorine ir praktine miestų bei rajonų, savivaldybių teritorijų planavimo patirtimi parodyti esmines deformacijas, kurios iškraipo b e n d r o j o planavimo esmę ir nuo kurių priklauso jo sprendinių igyvendinimo sẻkmė bei apskritai urbanistinio (teritorinio) planavimo vertè. Šiame straipsnyje urbanistinio planavimo deformacijos suprantamos kaip bet kokie nukrypimai (iškreipimai) nuo to, kas normalu, logiška, sistemiška, objektyvu ir pagrịsta ekonomiškai, socialiai bei kitais aspektais, o juos (nukrypimus) veikiančių veiksnių visuma ir yra šio straipsnio objektas. Planavimo kokybe turètų būti svarbiausias rūpestis, tačiau jos ịvertinimas yra sudètingas, todèl šiame straipsnyje autoriai siūlo santykinio vertinimo idėją bei argumentuotus principus, kurie turètų pakeisti pačios dabar veikiančios planavimo sistemos deformacijas ir tai ją modernizuotų.
\end{abstract}

Reikšminiai žodžiai: Teritorijų planavimo ịstatymas, urbanistinès deformacijos, bendrasis planavimas, planavimo kokybės įvertinimas.

\section{Ivadas}

Pirmoji deformacija - „teritorijų planavimo“ sąvokos atsiradimas. Iš pradžių buvo vartojama „teritorinio planavimo“ sąvoka. Tokiu pavadinimu 1993-1994 m. buvo rengiamas įstatymo projektas. Jis turejo pakeisti iki tol taikytos sovietinių metų planavimo sistemos (kurią sudare miestų planavimo ir užstatymo normos, taisyklès, rekomendacijos) principus, kartu ir miestų bei rajonų planavimo sąvoką. Viena vertus, tai buvo lyg simbolinis atsiribojimas nuo sovietinių metų ir iš dalies atspindejjo šios srities vystymo ir galimos raidos tuometines neapibrèžtumo nuotaikas. Kita vertus, tai reiškè, kad yra teritorinis planavimo aspektas, taip kaip egzistuoja ekonominio, socialinio ir kitokio planavimo rūšys, t. y. buvo rengiamas universalaus turinio istatymas, kuriame nebuvo numatyta atskirti urbanistiką nuo ruralistikos, nuo rajonų ir kitokių planavimo rūšių. 1995 m. Seimas patvirtino te r it o r i - j ų planavimo įstatymą. Šiandien atrodo, kad tai buvo miestų ir jų sistemų planavimo deformacijų pradžia.

Žinoma, tai ne vienintelè planavimo deformacijų priežastis ar šaltinis. Veiksnių yra labai daug. Jie keičiasi, vystosi. Veiksnių ittaka vis stiprëja. Iš esmès veiksniai yra tiesiogiai susiję su šalies rinkos raida ir visuomenès vertybių pokyčiais. Visa tai yra straipsnio objektas.

Šiame straipsnyje teritorijų planavimo deformacijos suprantamos kaip bet kokie nukrypimai (iškreipimai) nuo to, kas normalu, logiška, sistemiška, objektyvu ir pagrịsta ekonomiškai, socialiai bei kitais aspektais. Straipsnio autorių tikslas - remiantis teorine ir praktine miestų ir rajonų, savivaldybių teritorijų planavimo patirtimi parodyti esmines deformacijas, kurios iškraipo b e n d ro jo planavimo esmę ir nuo kurių priklauso jo sprendinių igyvendinimo sèkmè bei apskritai urbanistinio (teritorinio) planavimo vertè. 


\section{İstatymai}

Valstybès institucijos beveik $20 \mathrm{~m}$. kūrè universalią bet kuriụ teritoriju nuo keliu aru sklypo iki apskrities bei visos šalies teritorijos planavimo sistemą. Pirmasis teritoriju planavimo įstatymas ir įstatymo igyvendinamieji teisès aktai galiojo $9 \mathrm{~m}$. Tai buvo pasyvaus bendrojo ir nepaprastai aktyvaus detaliojo planavimo laikotarpis. Galbūt tai priežastis, dèl kurios nebuvo bandymų sistemiškai ịvertinti, kaip praktiškai veikia planavimo sistema. Tačiau tai nesutrukdè gana greitai ir netikètai $2004 \mathrm{~m}$. atsirasti antrajam visiškai kitokios planavimo ideologijos teritorijų planavimo įstatymui. Atrodytų nelogiška skubiai keisti sistemą, kai buvo žinoma, kad artimiausiu metu atsiveria realios bendrojo planavimo galimybès. Per $3 \mathrm{~m}$. paaiškejo, kad naujoji planavimo sistema yra ydinga. Tai patvirtino 2007 m. ir 2008 m. Vilniuje vykę urbanistiniai forumai bei Lietuvos Respublikos Vyriausybès Ministro Pirmininko $2008 \mathrm{~m}$. sausio $8 \mathrm{~d}$. potvarkiu sudarytos darbo grupès pasiūlymai (Darnioji plètra... 2008). Tačiau 2009 m. forumas parodé, kad viskas grịžo ị senąsias vèžes. Taigi, profesinès ir mokslinès visuomenès nuomonè ir iniciatyva, galinti padèti sukurti objektyvesnę planavimo sistemą, iš esmès buvo atmesta. Todèl nèra jokių garantijų, kad ateityje pavyks išvengti panašiu atvejų ir kad planavimo sistema bus vystoma nuosekliai bei objektyviai.

Tiesa, teritorijų planavimo įstatyme nuo jo prièmimo $2004 \mathrm{~m}$. kasmet buvo keičiama mažiausiai 3, daugiausiai - 24, iš viso 54 straipsniai. Pagrindinè dalis tai straipsniai, reglamentuojantys detalųji planavimą. Su bendruoju planavimu susiję iš viso buvo pakeisti 5 straipsniai, kurie neturèjo jokios įtakos planavimo ideologijai. Tai labai charakteringa proporcija, atspindinti tikrąji suinteresuotumą ir faktą, kad praktikoje bendrasis planavimas, kaip strateginio tipo dokumentas, yra sunkiau suvokiamas ir ne toks pragmatiškas kaip detalusis.

Pagrindinè teritorijų planavimo ịstatymo yda - nesistemiškumas. Nèra jokios užuominos, kad miestas ir mažos ar stambios jo dalys, miestų regionai, miestai ir kitos gyvenamosios vietoves - tai hierarchinès sistemos, tarpusavyje susijusios sisteminiais ryšiais. Todèl nèra ir suvokimo, kad miestą ar bet kurią kitą urbanistinę sistemą turime laikyti gyvu organizmu, kuris vystosi, bręsta, gali smukti ir kilti; turi struktūrą ir formą, kurios keičiasi pačios ar gali būti priverstinai keičiamos; turi gyvybines funkcijas tenkinančias sistemas ir šalutinius nepageidaujamus miesto funkcionavimo produktus; serga tam tikromis ,ligomis“. Urbanistinès sistemos yra atviros, jos gali konkuruoti arba bendradarbiauti. Sistemas veikia šalies ekonomikos būklè ir socialinė aplinka, vidaus ir užsienio rinka, globalizacija ir t. t. Todèl natūralu, kad planavimo sistema, neturinti minètų savybių ir ryšių, sukelia generalinio tikslo deformacijas. Keletas pavyzdžių:

- nuo modernaus, sparčias vystymosi galimybes turinčio miesto prie sąlygų miesto ekonominei ir kitokiai krizei kilti dèl nepagrịstų teritorinès ekspansijos ir vystymo prioritetu,

- nuo pastangų kurti stabiliai veikiančią urbanistinę sistemą prie neapibrèžto patikimumo sistemos formavimo. $2004 \mathrm{~m}$. teritorijų planavimo ịstatyme $\mathrm{f} \mathrm{u} \mathrm{n} \mathrm{k} \mathrm{c} \mathrm{in} \mathrm{is} \mathrm{zonavimas} \mathrm{yra} \mathrm{esminè} \mathrm{sąvoka,} \mathrm{kuri}$ suprantama kaip „<...> pagal bendrus vyraujančius požymius, naudojimo būda ar tvarkymo reglamenta atliekamas planuojamos teritorijos daliu išdèstymas" (Lietuvos Respublikos teritorijų planavimo ístatymas... 2004). Tai Atènų chartijos, paplitusios po II pasaulinio karo, reliktas, sovietiniais metais tapęs miestų planavimo prievole, o maždaug prieš $30-40 \mathrm{~m}$. pripažintas kaip miestų krizès veiksnys, - nuo siektinos socialinès integracijos prie de fakto jau egzistuojančios ir didèjančios socialinès atskirties, gyventojų sluoksnių ir grupių teritorinès diferenciacijos, uždarų gyvenamųjų kompleksų,

- nuo funkciškai integruotų urbanistinių darinių prie jų skeldejjimo ir naujų specializuotų atskirties erdvių kūrimo arba susitaikymo su tokių atsiradimu,

- nuo gyventojų mobilumo stabilizavimo prie dirbtinio jo didinimo, susisiekimo problemų eskalavimo. Šitie procesai apskritai nèra teritorijų planavimo įstatymo objektas, nors mobilumas yra pagrindiné urbanistikos paradigma.

Tos deformacijos reiškia, kad ịstatymas ir visa teritorijų planavimo sistema neturi atitinkamų priemonių valdyti miesto, kaip sistemos, vystymosi.

Labai aktuali pagrindinio tikslo formuluotè.

Urbanistinių sistemų egzistavimas apskritai, jų funkcionavimas ir vystymas visada turi tikslus - siekti gyvenimo gerovès, socialinès, ekonominès ir kitokios pažangos, kurti sveiką aplinką. Iš esmès tai ir yra pagrindinis tikslas. Tačiau tikslams pasiekti reikalingos prielaidos - darnus sisteminis miestų vystymas. Vystymas bus darnus, jeigu bus išvengta esminių planavimo ir vystymo disproporcijų, kurios deformuoja urbanistines struktūras, mažina funkcionavimo efektyvumą. Dažni atvejai: ịsisavinamos naujos teritorijos - nenaudojamos apleistos teritorijos, statomi 
gyvenamieji kompleksai - nevystoma socialinè infrastruktūra, didinamos darbo ir gyventojų santykio bei funkciškai integruotų bei specializuotų kompleksų teritorinès sklaidos disproporcijos. Tai ne vieninteliai disproporcijų tipai.

Disproporcijos yra neišvengiamos, svarbu tik jų dydis, trukmè ir pasekmių tikimybès. Jeigu jos nedidelès - sudaro laikinus nepatogumus. Jie traktuojami kaip neišvengiama, tačiau greičiau atsitiktinè blogybè, kurios pasekmès sukelia laikiną neesminę reakciją ir dažniausiai tai tiesiogiai neperauga ị struktūrines deformacijas. Tuo labiau kad gyventojai disproporcijas toleruoja, jeigu jas kompensuoja urbanistinių struktūrų privalumai (pasiekiamumo, prieinamumo, alternatyvų pasirinkimo įvairove ir t. t.). Didelių ir ilgalaikių 15-20 m. disproporcijų pasekmès paprastai būna esminès, jos susijusios su miesto ịvaizdžio ir patrauklumo smukimu, nepasitenkinimu gyvenimo ir aplinkos kokybės lygiu, dideliu lokaciniu mobilumu ar emigracija bei urbanistinių struktūrų deformacijomis.

Urbanistikoje problemos, suprantamos kaip poreikių ir galimybių disproporcijos, gali būti naudingos ir todèl iškeliamos specialiai. Tai viena iš efektyvių urbanistinio planavimo priemonių, plačiai naudojamų Vakarų Europos šalyse valdyti mobilumui, taupyti miesto žemei bei reguliuoti kitiems procesas. Tokios priemonès naudojimas Lietuvos miestuose neịmanomas, nes nei teritorijų planavimo ịstatyme, nei taisyklèse ar normose praktiškai nèra diferencijuotų reikalavimų strategijos. Ryškiausias pavyzdys - vietų automobiliams laikyti saugyklose normos, kurios atitinkamame reglamente nurodo statymo vietų skaičiu pagal funkcinius statinių tipus, nepriklausomai nuo ju dislokacijos mieste ir netgi nepriklausomai nuo miesto dydžio. Tačiau poreikio statyti automobili, rasti jam vietą, kur pastatyti, ir galimybių tai padaryti santykio įvairovè senamiestyje, miesto centre ir periferijoje, daugiabučių ir vienbučių namų rajonuose, didmiestyje ir mažame mieste, sostineje ir kurorte yra nepaprastai didelè. Tą įvairovę didina dienos ciklas, sezonai (pavyzdžiui, sezono metu poreikis pastatyti mašiną Palangoje išauga iki 9-10 kartų). Urbanistinio planavimo kontekste toks plačiai paplitęs suvidurkinimas yra visiškai netinkamas principas, nes jis neigia miesto, miestelio funkcionavimo ir ịvaizdžio, erdvių proporcijų, taršos bei kitų problemų originalumą ir dirbtinai riboja racionalių sprendinių paiešką.

Taigi galima teigti, kad teritorijų planavimo įstatymo yda yra ne tik nesistemiškumas, bet ir šabloniškumas bei baimè suteikti daugiau savarankiškumo profesionaliems planuotojams.
Kol kas urbanistikos mokslas ir praktika neturi adekvačios vietos jo sisteminei reikšmei. Urbanistikos mokslas yra išskaidytas ị specifines mokslo sritis, o praktikoje - i i ivairių ministerijų, tarnybų, departamentų atskirtą reguliavimą. Todèl bet kuri naujovè ar bendrasis planavimas susiduria su daugybe subjektyvių kliūčių ir prieštaringų reikalavimų, kurie de facto yra ịgiję veto teisę. Jų sumažètų, jeigu teritorijų planavimo kompetencija ịstatymais būtų suskirstyta $\mathfrak{i}$ sistemiškai labiau vienalytes sritis. Pirmasis ịstatymas turètų reguliuoti urbanistinị planavimą ir projektavimą. Pagrindiniai tikslai būtų susiję su šių sistemų efektyvumo vystymu. Antrojo įstatymo kompetencija ir objektas būtų agrarinès ir natūralios (gamtinès) teritorijos, užpildančios neurbanizuotas teritorijas. Tikslai - labiau specifiniai ir technologiniai, susiję su žeme bei miškų ùkio gamyba, priežiūra ir vystymu.

Tai bendrojo planavimo objektai. Jų bendrieji (ar kitu pavadinimu) planai turètų būti vieninteliai strateginiai dokumentai. Egzistuoti tokiu statusu kaip dabar specialieji planai neturi jokio pagrindo. Tai nesąmoné, kai netgi neesminè sistemos dalis tampa viršesnè ir nepriklausoma ne tik nuo planavimo ir vystymo sistemos, bet ir kitais aspektais. Nieko panašaus neįmanoma rasti kitose šalyse. Tokie planai nesukuria naujos kokybès, taip skatinama socialinès, ekonominès ir aplinkos sričių dezintegracija, o tai prieštarauja valstybès deklaruojamai darniajai plètrai. Dar viena nesąmonè - BP po $10 \mathrm{~m}$. nustoja galioti ir pradedamas rengti naujas planas. Tiesa, per ši laikotarpị kai ką galima įterpti, bet tai esmès nekeičia. Dabartinis teritorijų planavimas yra nustumtas ị procedūrų ir esamos būklès inventorizavimo bei ryškų privačių interesų dominavimo kelią, o tapdamas procedūrų grandine praranda profesionalios veiklos požymius.

Apskritai naudinga atsisakyti dabartinès planavimo ideologijos, kurioje susipina vizijos su neveiklumu. Kai kurios disproporcijos beveik fantastinès - pavyzdžiui, siūlymai rengti olimpines žaidynes (Srèbalius 2010) ir planuoti jų infrastruktūrą Lietuvoje; įrengti metropoliteną Vilniuje; Širvintų specialiajame plane gyvenamųjų teritorijų pasiūla viršija teorinị poreikị dešimtimis kartų; statomo nacionalinio stadiono Vilniuje talpa racionalaus naudojimo prasme yra pertekliné; nepradètą vidinį miestų modernizavimą pakeitè išorinès plètros ekspansija; naujos gyvenamosios teritorijos neturi socialinès infrastruktūros; gatvių ir inžinerinių tinklų vystymas atsilieka daugiau kaip $20 \mathrm{~m}$. 


\section{Informacija planavimui}

Urbanistinis, kaip ir bet koks kitas, planavimas be tinkamos informacijos teoriškai yra neįmanomas. Tačiau galimas ir kitoks interpretavimas: nèra informacijos nèra ir problemu. Tokią taktiką taikè ne vienas miestas ir savivaldybe. Taip atveriamas kelias urbanistiniam planavimui kaip savavališkam planavimui, neatsižvelgiant $\mathfrak{i}$ kitų nuomones, galimybes ir objektyvias sąlygas. Geriausiu atveju planavimas be informacijos galètų būti tik normatyvinis, jeigu toks apskritai gali gyvuoti rinkos sąlygomis.

Teritorijų planavimo ịstatymo VI skirsnis vadinasi teritorijų planavimo informacinè sistema. Jos svarbiausias elementas - duomenų bankas. Tokius bankus turètų kurti valstybès, apskričių ir savivaldybių tarnybos. Tačiau duomenų banko užuomazgą turi tik Vilniaus miestas. Iš dalies trūkumą laikinai kompensavo bendrovès, pastaruosius $5 \mathrm{~m}$. viešuosiuose pirkimuose laimejusios bendrojo planavimo darbus ir tam pagal savo supratimą sukūrusios duomenų bazę. Jų kokybė pagal esmines savybes nèra įvertinta. Paprastai kiekvienas planuotojas stengiasi mažinti pastangas ir finansinius resursus elementariai informacinei bazei suformuoti. Tačiau prielaidas kokybiškam urbanistinių sistemų planavimui gali sudaryti tik sisteminè informacinè bazè (bazès, nes informacijos turinys ir detalumas priklauso nuo planavimo mastelio):

p i r m a, ji turi apimt visus $\mathrm{G}-\mathrm{K}$ urbanistinius posistemius, nes:

G - tik žinomi gyventojų, verslo struktūrų bei bendri objektyvūs poreikiai ir interesai gali lemti planavimo tikslus ir esmę;

F - tik reprezentatyvūs duomenys apie fizinę ir funkcinę miesto struktūrą gali sudaryti pagrindą ją ịvertinti G poreikių (darbo vietų, būsto ir kt.) ir finansiniu galimybių, miesto funkcionavimo pasekmiu bei kitomis prasmèmis;

M - komunikacinio, lokalizacinio ir virtualaus mobilumo dydžiai, sklaida, dinamika ir kiti požymiai yra tiesiogiai susiję su F posistemiu ir jie lemia susisiekimo poreikius; M pokyčiai lemia žemès naudojimo, struktūrines mutacijas, gyventojų migracijos dinamiką;

S - visu rūšiu srautai komunikaciniuose koridoriuose kaip M pasekmé yra miesto sistemos funkcionavimo patikimumo indikatorius;

$\mathrm{P}$ - miesto sistemos funkcionavimo ir vystymosi pasekmès (tarša, laiko nuostoliai, saugos lygis, žemés plotai ir t. t.) yra svarbiausi planavimo vertinimo kriterijai;
$\mathrm{K}$ - kaina, kurią turètų mokèti visuomenè ir kiekvienas bendruomenès narys už gyvenimo kokybę ir veiklos mieste sąlygas, yra lemiamas planavimo kokybès bei sprendinių igyvendinimo veiksnys;

a n $\mathrm{r}$ a, bazę turi sudaryti mažiausiai trys dalys: retrospektyvinio laikotarpio, esamo periodo ir prognozès rezultatų. Tai būtų prielaida monitoringo užuomazgai,

t r e č i a, planuojamojo objekto duomenų bazę turi sudaryti visų miesto posistemių ir visų struktūrinių elementų (rajonų, kvartalų ir pan. tikslumu) duomenų visuma, kuri identifikuoja funkcinius, fizinius, socialinius skirtumus, deformacijas ir visa kita, kas reikalinga planavimui,

k e t v i r t a, duomenų bazès turinys turi koreliuoti su urbanistinio planavimo koncepcija. Koncepcijų gali būti daug. Plačiąja prasme oficiali koncepcija yra darnioji plètra. Tačiau urbanistinio planavimo kontekste ji išlieka politiniame ir deklaracijų lygmenyje, todèl kol kas bazès turinys lieka problema,

p e $\mathrm{n} \mathrm{t}$ a, mažai detalizuotas bazès turinys gali neatskleisti visų svarbių procesų, reiškinių sklaidos. Per didelè detalizacija - atsiranda perteklinè informacija, kuri yra nereikalinga našta, papildomos išlaidos,

š e š t a, esminiai dalykai: informacija renkama, kaupiama konkretiems tikslams pasiekti (identifikuoti, analizuoti, modeliuoti ir kt.), ji turi būti vertinga (galimas palankus jos naudojimo efektas), patikima ir reprezentatyvi.

Tokios išsamios informacinès bazès neturi nei vienas miestas. Tam yra svarių priežasčių. Visų pirma, planavimo sistema praktiškai ignoruoja informacini aprūpinimą. Irodymas - miestu ir miesteliu bendrųju planų rengimo taisykliu (Lietuvos Respublikos... 2006) 25 str.: „esamos büklès analizés stadijoje naudojami paskutiniuju 3 metu statistiniai ir kiti duomenys. Planavimo salygas išduodančios ir teritoriju planavimo dokumento sprendinius derinančios institucijos, pareikalavusios atlikti ivertinima, bendrojo plano rengimo organizatoriui turi pateikti tyrimuduomenis". Ši taisyklè neveikia. $3 \mathrm{~m}$. statistiniai duomenys neteikia jokių prielaidų buvusioms tendencijoms identifikuoti, tuo labiau jų negalima naudoti $20 \mathrm{~m}$. laikotarpio koncepcijai rengti. Antra, oficialios statistikos objektas yra administraciniai vienetai, todèl nèra jokios informacijos apie vidinius struktūrinius miesto elementus. 25 str. minimos institucijos ne teikia, o atvirkščiai - esant specifiniam suinteresuotumui, reikalauja tyrimų duomenų iš bendrojo plano rengèjų. 
Faktas, kad pastarųjų $5 \mathrm{~m}$. laikotarpiu visi parengti bendrieji planai yra patvirtinti, reiškia, kad bendrovių suformuoti duomenų rinkiniai buvo pakankami sprendiniams pagrịsti. Todèl natūralu klausti, kam reikalingas siūlomos informacinès sistemos tipas, iš pirmo žvilgsnio sudetingesnis ir brangesnis. Atsakymas trumpas - planavimo objektyvumui ir pagrisstumui, kokybei.

Tačiau sukurti net bet kokią informacinę planavimo bazę nèra paprasta, nes pagrindinis apie 80 proc. duomenų savaime neegzistuoja. Juos galima gauti tik tyrimais. Be to, praktika rodo, kad dažnai abejojama esamos būklès duomenų tikrumu dèl subjektyvių veiksnių ir dèl neiprasto tikimybinio aspekto. Paklaidos yra neišvengiamos. Todèl, pavyzdžiui, oficiali apsirūpinimo būstu statistika, neaišku, kokiu mastu, koreliuoja su realia situacija dèl visada egzistuojančių būsto dydžio ir juose gyvenančių šeimų dydžių disproporcijų, deklaruojamos ir tikrosios gyvenamosios vietos ar emigracijos mastų, sodų namų ir kito antrojo būsto naudojimo.

Ypač komplikuota prognozè. $1992 \mathrm{~m}$. Ukmergès miesto generaliniame plane numaty tos gyventojų skaičiaus augimo tendencijos turèjo padidinti gyventojų skaičių 2010 m. iki 50 tūkst. gyv., faktiškai 2008 m. buvo 27 tūkst. gyv. Statistiné prognozė 2020-2023 m. 23-28 tūkst. gyv. Tam tikruose bendruomenès sluoksniuose ji buvo îvertinta kaip pesimistinis požiūris $\mathfrak{i}$ miesto pletros potencialą. Tačiau potencialo pervertinimas yra blogiausias atvejis, nes tada gyventojų skaičius tampa spekuliacine priemone; jis lemia nepagrịstai dideles pretenzijas plèsti socialinę, techninę ir kitą infrastruktūrą bei pretenduoti ị atitinkamus finansinius resursus. Praktika patvirtina, kad tai eskaluoja nebaigtas urbanistines struktūras ir tokiu statusu jų egzistavimą tęsia apie $20 \mathrm{~m}$., gali išlikti ir neapibrežtą laikotarpi.

Panašiai ir su būsto prognoze. Dabartinis apsirūpinimo lygis - $25 \mathrm{kv}$. m/gyv. Pagal 2005-2007 m. Vilniaus miesto ir apskrities, Šilutès rajono, Druskininkų gyventojų apklausas, apie 40 proc. ir daugiau respondentų planavo įsigyti tinkamesnị (didesnị ir ypač nedaugiabučiame name) būstą. Tai didelis hipotetinis plètros potencialas. Dabartiniame urbanistinio planavimo kontekste būsto poreikis yra vienintelis plètros parametras, nes gamybinès ir kitokios infrastruktūros kūrimas visiškai neapibrèžtas. Būsto poreikị bent iš dalies galima prognozuoti, nes platesniame kontekste statistiné analizè rodo, kad apsirūpinimo būstu lygis tiesiai koreliuoja su šalies BVP. Kelerių metų optimizmą dèl žinomų priežasčių pakeitè būsto plètros nuos- mukis, o krizès raidos prognozè bendrojo planavimo požiūriu yra nepatikima. Todèl be įrodymų imamas bet kuris aprūpinimo lygis - 35 (maždaug ES vidurkis), $55 \mathrm{kv}$. m./gyv. (Danijos lygmuo) - ir taip apskaičiuojami neapibrèžtos, teisingiau, mažos tikimybès miesto vystymo poreikiai - žemès, infrastruktūros ir t. t.

Prognozès, konkrečiai būsto, tikslumo problema aktuali ir kitoms šalims. Tačiau, pavyzdžiui, Prancūzijoje ji siejama su konkrečiu miesto teritorinio vystymo valdymu - su vystymo proporcijų harmonizavimu senose ir naujai ịsisavinamose teritorijose, įvertinant gyventojų senejimo, šeimų dydžių, gyvenimo būdo ir komforto, prioritetų kaitos tendencijas (Lemaitre 2007). Lietuvoje ši problema platesnè, nes ji yra sisteminè ir apima visos informacinès bazès kūrimą. Akivaizdu, kad jos kūrimas nèra elementarus duomenų rinkimas, kurị galima „patobulinti“ "taisyklèmis, rekomendacijomis, instrukcijomis ar šio straipsnio tezèmis. Tam reikalingos radikalesnès priemonès.

Verta paminèti tokias informacinio aprūpinimo pagrindą sudarančias priemones:

a) Reiktų atsisakyti $10 \mathrm{~m}$. ir $20 \mathrm{~m}$. koncepcijos galiojimo laikotarpių ir pereiti prie tęstinio planavimo. Tęstinumas reikštų, kad sprendiniai galioja tol, kol jie iggvendinami arba randami geresni sprendiniai, esant reikalui - pildomi naujais sprendiniais. Koncepcija taptų neterminuotu orientyru, kurio turinys tokiu pat būdu galètų būti tobulinamas.

b) Tęstinio planavimo ritmas turètų priklausyti nuo miesto vystymo tempo ir problemų identifikavimo dažnio. Todèl kiekvienas miestas turètų išlaikyti monitoringo sistemą (MS) - nuolat veikiančią, nesudètingą, sudarytą iš esminių indikatorių. Ja remdamasi savivaldybė galètų priimti sprendimą dèl studijos (studijų) rengimo.

MS užuomazgos formaliai yra, tačiau jos neveikia. Priežastys ịvairios: savivaldybès neturi pajègumų ir lèšu, patirties; MS nereikalinga, nes mažu miestų raida silpna; laikoma nepagrista prievole, nes kas $10 \mathrm{~m}$. bus rengiamas naujas bendrasis planas; MS išlaikymas brangus, efektas neaiškus. Didžiausia problema - duomenų kaupimas pagal rajonus.

c) Miesto problemų sisteminis įvertinimas, konceptualūs sprendimo būdai turètų priklausyti studijų kompetencijai. Jos turètų būti sisteminès, suformuotos priklausomai nuo objekto ir tikslų su atitinkama originalia duomenų baze. Studijos - nepriklausomas mokslinis tiriamasis darbas (universitetų kompetencija), kuris tiesiogiai neįeitų i planavimo procesą. 
d) Tačiau visa urbanistinių studijų medžiaga turètų būti ta informacinè bazè, kuria remiantis planuotojas (įmonė) parengtų konkrečius variantinius sprendinius ir geriausiais papildytu bendrąji planą, o jų rodikliais - monitoringo sistemą.

e) Taip bendrasis planas palaipsniui turètų tapti pagal objektyvų poreikị atsinaujinančiu rekomendaciniu dokumentu.

Šią logišką veiksmų seką galima vadinti planavimo sistemos esminio modernizavimo supaprastintu modeliu - ideja. Idejja diskutuotina, nes visada galima rasti Ł̇vairiausių rizikos elementų. Blogiausias variantas planavimo sistemos vystymo uždarumas.

\section{Planavimo kokybė}

Planavimo kokybė turetu būti svarbiausias rūpestis, nes tai yra prielaida siekti pagrindinio planavimo tikslo - sudaryti sąlygas didinti gyvenimo kokybę.

Veikiančioje planavimo sistemoje nèra dokumento, kurị galètume vadinti urbanistinio (teritorijų) planavimo vertinimo metodika ar sistema. Tačiau faktiškai vertinimas vyksta, nors kokybės sąvoka nèra vartojama.

P i r m a, svarbiausias yra politinis vertinimas: savivaldybès tarybos pritarimai bendrojo plano dalims planavimo proceso laikotarpiu ir BP kaip galutinio produkto tvirtinimas.

A n $\mathrm{r}$ a, tikrinama, ar visos privalomos procedūros laiku ir tinkamu būdu ịvykdytos, neprieštarauja teisès aktams.

Tr e č i a, tikrinama, ar įvykdyti visi išankstinių planavimo sąlygų reikalavimai, nors jas rengusių institucijų reikalavimai tarpusavyje nèra derinti.

Ket $\mathrm{v}$ i $\mathrm{r}$ a, vadinamasis BP sprendinių derinimas su Kelių direkcija, aplinkos apsaugos departamentais ir kitomis miškotvarkos, saugomų teritorijų tarnybomis, gretimomis savivaldybėmis bei su jų administruojamais specialiaisiais, bendraisiais planais, programomis ir pan. yra vienpusis, nediskutuojamas ir nesisteminis veiksmas.

P e $\mathrm{n} \mathrm{k} \mathrm{ta,} \mathrm{ypatingą} \mathrm{galią} \mathrm{turi} \mathrm{visuomenès} \mathrm{daly-}$ vavimas. Tai prieštaringas procesas, kuriame sunku kategoriškai atskirti asmeninius privačius interesus nuo bendruomenès interesų. Kol kas nesusiformavo konstruktyvaus visuomenès dalyvavimo planavimo procesuose tradicijos. Šiuo metu vykstančios diskusijos dèl esminès sąvokos ,,viešasis interesas“ yra teigiamas dalykas, tačiau konkretaus naudingo bendrajam planavimui rezultato nèra.
Š e št a, planavimo procesuose aktyviai dalyvauja privačios struktūros. Natūralu, jos suinteresuotos sau palankia planavimo, projektavimo sistema. Tačiau ne visada jų inicijuotos reglamentų pataisos yra pagrịstos kitais ne pelno ir rinkos plètros, o gyvenimo kokybès argumentais.

S e p t i n $\mathrm{t}$ a, rinkoje veikia samdomi ar savo iniciatyvą išreiškiantys ekspertai, recenzentai, nors teritorijų planavimo kontekste toks institutas nera numatytas. Tai subjektyvaus vertinimo (paprastai kokybinio aptarimo forma) būdai. Iš dalies jie tinka fizinei struktūrai ịvertinti tol, kol naudojami ịvaizdžio, stiliaus, ritmo, formos ir panašūs kriterijai.

Tokia padrikai veikiančių subjektų visuma nieko negali îvertinti, ji negali net konstatuoti, ar bendrojo plano numatyta vystymo kryptis iš esmès kaip visuma atitinka oficialią darniosios pletros koncepciją, ar ne; ar ji efektyvi socialiai ir ekonomiškai; ar tai pakeliama finansinè ir kitokia našta visuomenei. Ta visuma niekaip nèra pasiruošusi, o planavimo sistema nesudare prielaidų ir mechanizmų kompromisinių pagrịstų sprendinių paieškai. Teoriškai urbanistiniai sprendiniai tik tokie ir įmanomi. Formaliai galima tvirtinti, kad dalis dabartinių bendrųjų planų sprendinių yra originalūs ir kompromisiniai, kiti - priverstiniai ar įbrukti, dar kiti - nesuderinamai priešiški (pavyzdžiui, saugojimo režimas su vystymo režimu). Deformacijų tipų daugybè. Keista, tačiau tokiems planams apibūdinti kartais vartojama netgi optimalumo sąvoka.

Tokia situacija yra susijusi su tuo, kad esama planavimo sistema nedeklaruoja kompromisų paieškos, tačiau tokios paieškos de fakto suverstos planuotojui (imonei), jam nesuteikus atitinkamų teisių. Todèl stebime savotišką paradoksą - pastaruoju metu parengti bendrieji planai yra patvirtinti, t. y. jie perejo visus anksčiau minètus septynis, o gal ir daugiau ,filtrų“. Todèl atrodo, kad nèra jokių problemų.

Tačiau tai pasiekiama ilgai trunkančiomis diskusijomis, derybomis bet dažniausiai - BP rengejjų nuolaidomis dèl esminių dalykų ir smulkmenų (ne paslaptis - dèl ambicijų, suinteresuotumo ir t. t.). Tam nepagrịstai eikvojamas darbo laikas, žmogiška energija, lèšos. Šios ir kitos neracionalios išlaidos sudaro apie 2/3 BP rengimo trukmès. Šiandien niekas negali apibendrintai atsakyti, kokios visu „filtrų“ pasekmès, t. y. kuo ir kiek bei kieno naudai (gyventojų, verslo, savivaldybès ir kt.) BP rengèjo variantas skiriasi nuo patvirtinto BP. Žinoma, kiekvienas BP yra originalus, todèl kokybè priklauso ne vien nuo planavimo sistemos 
tobulumo, planavimo subjektų kompetencijos, bet ir nuo objektyviai egzistuojančios miesto sistemos raidos ypatybių ir būklès. Todèl planavimo kokybès ịvertinimas yra sudètingas, tuo labiau kad iki šiol nèra susitarta dèl vertinimo kriterijų. Šiame straipsnyje autoriai siūlo idèją, kad vertinimas turètų būti tik santykinis. T. y. atskaitos pradžia būtų esamos būklès vertinimo parametrai, o jų palyginimo su planuojamais skirtumai parodytų tikètinas teigiamas ar neigiamas tendencijas.

Profesine prasme vertinimo sistema yra universali urbanistinio planavimo priemonè. Pirma, ji yra urbanistinių procesų valdymo pagrindas. Antra, profesionalus planuotojas privalo turèti sisteminę objektyvių argumentų visumą diskusijoms su visuomenès grupèmis, politikais, sektorinèmis tarnybomis. Trečia, be vertinimo sistemos neįmanomas variantinis planavimas ir tęstinio planavimo principo igyvendinimas.

Urbanistinio planavimo priemone galejo būti strateginis pasekmių aplinkai vertinimo (SPAV) ir bendrojo planavimo (BP) sprendinių poveikio vertinimo dokumentai. Tačiau jie yra tik a št $\mathrm{u} n \mathrm{t}$ a $\mathrm{s}$ i $\mathrm{s}$ ir d e vi in ta s is "filtrai“. Jie nepadeda sukurti naujos kokybès ir neturi liekamosios vertès, nes tai vienkartiniai aktai. SPAV problema ta, kad iš anksto nèra jokios garantijos, kad miesto vystymasis vyks tokiu tempu ir tokiu turiniu, kaip numato bendrasis planas (neminint finansinių resursų galimybių). Neprognozuojamas imoniu ir technologijų tipas bei modernumo lygis, naudojamos žaliavos, energijos ir vandens poreikiai. Tą pati galima pasakyti apie gyventojų poreikių kaitą, finansines galimybes ir t. t. Miestų ir miestelių teritoriju bendruju planu rengimo taisyklès (Lietuvos Respublikos... 2006) reikalauja, kad BP sprendiniu poveikis būtų vertinamas tokiais aspektais:

„<...> poveikio teritorijos vystymo darnai ir (ar) planuojamai veiklos sričiai; poveikio ekonominei aplinkai (ükio ir atskiru jo sektoriu raidos procesams, investiciju ir verslo salygoms, valstybes ir savivaldybiu biudžetams); poveikio socialinei aplinkai (ivairiems socialiniams procesams bei socialinems grupems); poveikio gamtinei aplinkai ir kraštovaizdžiui (gamtinés aplinkos kokybei, kraštovaizdžio struktūrai ir ekologinei pusiausvyrai, gamtos ir kultūros paveldo objektu išsaugojimui)“.

Tačiau be atitinkamos informacijos, metodikos ir kriterijų tai neịveikiama užduotis. Geriausiu atveju, remiantis urbanistikos žiniomis, galima tik aprašyti galimas raidos tendencijas, išskyrus poveikị ūkio raidai, biudžetams, gamtinès aplinkos kokybei ir pan.

Bendrojo plano taisyklèse sprendinių vertinimo objektas, kalbant urbanistinemis kategorijomis, yra tradicinè funkcinè ir fizinè struktūra. Tai yra nepagrịstas supaprastinimas. Objektas turi būti miesto sistema.

Todèl planavimo kokybę reikètų suprasti kaip urbanistinès sistemos, kurioje struktūrai tenka esminis vaidmuo, paieškas. Ieškoma tokios struktūros, kuri skatintų gyvenimo kokybės augimą, o augimo kaina būtų pakeliama našta visuomenei. Tai permanentinis procesas - tęstinis planavimas. Struktūros kūrimo ir tobulinimo reikšmingumas grindžiamas ịrodytais faktais, kad morfologiniai, funkciniai ir socialiniai urbanistinių struktūrų tipai koreliuoja su urbanistinès sistemos funkcionavimo pobūdžiu ir su teigiamomis ar neigiamomis funkcionavimo pasekmemis (taip pat ir su šalutinių produktų emisijos dydžiais). Tai yra $\mathrm{u} r \mathrm{~b}$ a $\mathrm{n}$ i s t i n i o vertinimo e s mè. Vertinimas turi apimti visus urbanistinés sistemos posistemius, kurie čia trumpai yra surašyti kaip logiška skirtingų, tačiau tarpusavyje susijusių tiesioginiais ir grịžtamais ryšiais pasekmių seka:

- gyventojų, valstybės ir kitų interesų sritị,

- fizinę ir funkcinę struktūrą,

- vidinị ir išorinị mobilumą,

- pèsčiųjų, keleivių ir transporto priemonių srautus komunikaciniuose koridoriuose,

- taršos emisiją (triukšmą, oro taršą, barjero efektą ir t. t.),

- poveiki gyventojams, gamtiniams kompleksams, statiniams ir pan.,

- vidinę ir išorinę urbanistinès sistemos funkcionavimo kainą,

- gyventojų, valstybės ir kitų interesų pokyčius.

Taigi, jeigu pagrindinio planavimo tikslas - gyvenimo gerove, socialinè ir ekonominè bei kitokia pažanga, sveika aplinka - yra tik idèja, tai miesto sistemos variantas, pasižymintis minimaliomis neigiamomis pasekmėmis ir poveikiu, galètų būti bendrojo plano sprendiniu. Savaime aišku, kad toks sprendinys turètų atitikti konkrečios ekonominès, socialinès, gamtinès, teisinès aplinkos galimybes ir reikalavimus. Jeigu ne, ieškomas kitas variantas, kuris, svarbiausia, būtų pakeliama ir finansinè našta visuomenei. Taip vertinimo procesas savaime taptų urbanistinio planavimo priemone. Vertinimas būtų aiškus, konkretus ir kompromisinis, tačiau nesietinas su praktiškai neišsprendžiamu uždaviniu - „,...> optimizuoti teritorijos urbanistinę struktūrą ir infrastruktūros sistema" "(Lietuvos Respublikos... 2004). Miestas kaip gyvas organizmas vystosi, keičiasi poreikiai ir galimybès, sensta, todèl kiekvienas miestas paprastai keičiasi savaime arba jo vystymo pastangos atsilieka nuo laiko reikalavimų ir 
madų. Todèl daugeliu atvejų tai bus susiję su struktūriniais ir kitokiais pertvarkymais, kuriems apibūdinti vartojamos renovacijos, revitalizacijos, rekonstrukcijos ir kitos sąvokos.

Tokiai sistemai sukurti reikalingos prielaidos:

- planavimo procesas turi būti aprūpintas statistine ir kitokia informacija. Ji turètų būti susieta su indikatoriais ir skirstymu rajonais, tai leistų suformuoti adekvatų miesto ar kito sisteminio darinio modelį. Vertinimo sistemai reikalinga indikatorių sistema, kuri išreikštų oficialiai pripažistamą darniosios plètros doktriną. Akivaizdu, kad naudoti kitas doktrinas kol kas būtų nepraktiška. Problema ta, kad Lietuvoje darniosios plètros supratimas ịtvirtintas politiniame lygmenyje kaip idealiai subalansuota doktrina. Kitos šalys perejo ị konkretaus planavimo ir projektavimo lygmeni bei suprato, kad darnioji plètra ne trumpalaikis ir ne galutinis tikslas, o tik kryptis, kurią stengiamasi išlaikyti.

- Todèl vertinimo sistema turi veikti kaip monitoringo forma. Tokiu atveju galimas ne tik planavimo variantų ivertinimas, bet ir atrinkto varianto ar esamos būklès „darnumo“ konstatavimas, taip pat penkmečių ar dešimtmečių tendencijų interpretavimas. Kiti privalumai: miestų lyginamosios analizès galimybė; netenka prasmès (išskyrus ypatingus atvejus) bendrojo plano „esamos būklès“ privalomoji dalis.

- Šiuolaikiniame dinamiškame pasaulyje urbanistinis planavimas be matematinio modeliavimo aparato tampa vis primityvesnis, ilgai trunkantis, nepatikimas, neturintis operatyvumo ir ateities. Instrumentiniai triukšmo, taršos ir kiti panašaus tipo tyrimai daro teigiamą ịspūdị viešoje erdvejje, bet jie yra brangūs ir neefektyvūs. Juos senokai galejjo pakeisti matematiniai modeliai.

Taigi iš esmès reikèjo prieš $10-15 \mathrm{~m}$. pradèti nuosekliai kurti kiekvieno miesto e. modelí, o vèliau - miestų tinklus. Kol kas atsilikimas nuo kitų šalių sparčiai dideja. Todèl e. modeliai skamba kaip utopija dèl daugelio priežasčių: kompetencijos stokos ir subjektyvių interesų; nepasitikejjimo; rizikos, kad bus stengiamasi išlaikyti dabartinę painią planavimo sistemą. Objektyvūs veiksniai: pradinès investicijos, absoliuti dauguma savivaldybių dabar būtų nepajegios veikti tokioje sistemoje (ir dabar pačios savivaldybès nerengia BP). Išeitis - silpnus pajègumus ir gebejjimus galètu kompensuoti tinklų principu veikianti nepriklausoma teritorijų planavimo ir urbanistikos agentūra, teikianti ivairias planavimo paslaugas, konsultacijas. Svarbu ir tai, kad ji būtų pajègi eksploatuoti monitoringo sistemą (Darnioji plettra... 2008). Čia svarbus vaidmuo turètų tekti universitetams.

\section{Plètros valdymas}

Plètros valdymas yra savivaldybių kompetencija. Tačiau tarp valdymo veiksmų ir bendrojo planavimo yra prieštaringi abipusiai ryšiai. Pats paprasčiausias bendrojo plano apibūdinimas trimis požymiais - 10-čiai m. numatyti darbai, siekiami rezultatai, užduoties vykdymo tvarka. Darbai numatyti, tačiau igyvendinimas paprastai nèra sklandus dèl finansinių, organizacinių, techninių ir kitokių veiksnių. Per pastaruosius $20 \mathrm{~m}$. daug miestų ir savivaldybių dešimtmetị ir ilgiau gyveno apskritai be BP. Kiti miestai, nors ir turejo planus, daugelio sprendinių nepajegè igyvendinti. Dar kituose sprendinių igyvendinimas atsilieka keliais dešimtmečiais. Todèl miesto funkcionavimas paprastai būna kitoks negu planuotas. T. y. planuotoji kokybė realiai naudinga tik kaip tikslų orientyras ir kaip planuotojo kompetencijos bei atlikto darbo įvertinimas.

Vystant tęstinio planavimo idejją, svarbiausi tampa BP numatytų ir nenumatytų, tačiau pretenduojamų statyti objektų veiklos pasekmių miesto sistemai ìvertinimai (funkcinei ir socialinei integracijai, gyventojų mobilumui, susisiekimo sistemai, inžinerinei infrastruktūrai, gyvenamosios aplinkos kokybei ir t. t.). Šių ịvertinimų rezultatai būtų reikalingi, visų pirma, politiniam sprendimui. Antra, esant teigiamam sprendimui, rezultatai yra svarbūs nustatant investuotojų, savivaldybès, finansinius gyventojų tarpusavio ir kitokius įsipareigojimus bei sąlygas, susijusias su laikinais statybos teisès ribojimais dèl technogeninių ir smulkaus paslaugų verslo rizikų (pavyzdžiui, miesto centre), taip pat su kompensacijomis dèl laikinų nepatogumų ar neigiamos įtakos bei del kompleksinio funkcinio teritorijų i̇sisavinimo (socialinès, techninès, susisiekimo infrastruktūros, verslo ir kt.) ir t. t. Trečia, bendrojo plano sprendinių igyvendinimas statistine prasme yra atsitiktinis, nes nėra sąryšio su šalyje veikiančia finansavimo sistema. Savivaldybiu įsipareigojimai erdvejje ir laike finansuoti bendro naudojimo objektų statybą, dalyvauti vadinamuosiuose PPP projektuose yra problematiški.

Visa tai potencialiai yra laikinų arba ilgalaikių urbanistinių deformacijų šaltinis. Todèl gyventojų ir miesto vystymo labui reikalingas specialus įstatymas, kuris sąlygiškai vadintinas urbanistinių sprendiniu í g y ve n di n i mo įstatymu. Jo turinys būtų susijęs ir su miesto ekonomikos elementais bei princi- 
pais. Miesto ekonomika (Regulski 1982; Harvey 1992; O'Sullivan 2002), kaip šaka, kurios objektas yra miesto sistema ir jos funkcionavimas, Lietuvoje nèra išvystyta ir dažnai neteisingai suprantama.

Viešojo transporto era anksčiausiai dar prieš II pasaulinį karą baigèsi JAV, Vakarų Europoje maždaug apie 1960 m., Lietuvoje - 1990-1995 m. Tai esminiai lūžiai bet kurios šalies urbanistikoje. Lietuvos miestuose dingo galimybė lengvai valdyti miestų (išskyrus mažus ir kompaktiškus) plètrą pagal tuo metu veikusius miestų generalinius planus, kurie ir buvo pagrindinès miesto plètros priemonès. Iki tol esminių prieštaravimų tarp generalinio plano ir plètros sprendinių nebuvo. Dabar tai istorija. Privati žemès nuosavybè, masiné automobilizacija ir kiti rinkos veiksniai sukūrè pasirinkimo alternatyvas, svarbiausia gyvenamosios, pastaruoju metu ir verslo, gamybos erdvès pasirinkimo laisvę. Tai paskatino lokalizacinę migraciją, kurios ryškiausi urbanistiniai požymiai yra ekstensyvaus ir nestruktūrizuoto užstatymo ekspansija, visos miesto sistemos fizinès bei funkcinès makrostruktūros esminès deformacijos. Jos sukelia pasekmių grandines, pavyzdžiui: pasikeite užstatymo tipų proporcijos, išaugo žemès poreikis (kv. m/gyv.), mobilumas (kel. km), automobilių rida (aut. $\mathrm{km}$ ), gatvių prisotinimo laipsnis (aut./gatvių tinklo $\mathrm{km}$ ); dèl to atsirado kitos pasekmès - didejja taršos emisija, eismo konfliktų tikimybè; ir pasekmių pasekmès - auga gyventojų ir apskritai visuomenès išlaidos. Svarbiausia, kad šių pasekmių plačiąja prasme išlaidos auga sparčiau negu gyventoju skaičius. Lietuvoje tokie procesai laisvai vystosi, jie nèra identifikuoti kaip esminè problema. Netgi atvirkščiai, bandymai bendruosiuose planuose reguliuoti chaotišką plètrą negavo reikalingų pritarimų. Vakarų Europos ir kitose šalyse jau apie $50 \mathrm{~m}$. urbanistinio planavimo principai nuolat papildomi naujomis vystymo reguliavimo priemonemis urbanistinès politikos forma arba tai būna planuotojo kompetencija konkrečiame projekte (Rockingham... 2008; Stirling... 2006; Edinburg... 2007; Two Rocks... 2008, Pęski 1999; De Brest... 2008, Juškevičius, Jauneikaitè 2008).

Kiti deformacijų aspektai: savaime suprantama, kad gyventojų ir verslo struktūrų sumanymų ribojimai būtų nesąmonè. Tačiau sumanytos veiklos rūšys, jų teritorinè sklaida kaip informacija bendrųjų planų rengejjams dažniausiai nebūna žinoma. Todèl neịvertinta ir neatsispindi bendruosiuose planuose. Tik atsitiktinai gali sutapti su privalomais BP sprendiniais, kategoriškomis žemès paskirties, naudojimo būdų ir pobūdžių, funkcinio zonavimo bei kitomis dogmomis. Todèl de facto lygiagrečiai veikia oficialus ir neformalus planavimas. Bendrojo plano sprendiniai yra žinomi, viešai deklaruoti, turi bendruomenès, tikriau - paprastai nedidelès jos dalies - pritarimą. Tačiau iggyvendinimo tikimybè, ypač dèl finansinių išteklių, nežinoma ir savivaldybès lygmenyje sunkiai prognozuojama. Gyventojų ir verslo struktūrų subrandinti sumanymai teoriškai turètų didžiausią bent jau finansine prasme igyvendinimo tikimybę. Praktiškai ji gali būti labai maža. Akivaizdu, kad santykiai tarp šių planavimų turètų būti racionalesni.

Dalị šių deformacijų panaikintų tęstinis planavimas. Tačiau yra daug atvejų, kai miesto faktinès sistemos (ypač didmiesčių) vystymą izoliuotai valdo skirtingos savivaldybès ir atitinkamai veikia skirtingų strategijų bei tikslų bendrieji planai. Be įrodymų aišku, kad toks miesto sistemos suskaidymas negali būti efektyvus. Neaišku kodèl, tačiau esama praktika nenumato savivaldybių pletros planų ir igyvendinimo veiksmų konsolidacijos - susivienijimo bendrai efektyvesnei veiklai. Panaši situacija susiklosto visur, kur administracinèms teritorijoms, regioniniams parkams rengiami atskiri bendrieji ar kitais pavadinimais panašūs planai, nors tos teritorijos yra tik realiai veikiančių ivvairaus hierarchinio rango sistemų dalis.

Todèl dauguma parengtų miestų ir savivaldybių bendrųjų planų turètų būti konsoliduoti. Konsoliduoti bendrieji planai (KBP) pakeistų nereikšmingus ir nereikalingus apskričių BP. Konsoliduojančiu struktūriniu faktinio miesto, aglomeracijos ar metropolio elementu turètų tapti bendras gatvių ir kelių bei viešojo susisiekimo tinklas. Nuo jo priklauso ne vien utilitarinè susisiekimo funkcija, bet ir visos miesto sistemos funkcionavimo kokybè bei neigiamų išorès efektų minimizavimo prielaidos. Tai būtų pirmoji miestų vystymo valdymo prielaida, kurioje vyrautų teritorinès konsolidacijos aspektas. Kartu tai pagrindas tinkamai lengvojo automobilio ir viešojo transporto vystymo sklaidai ir proporcijoms nustatyti. $1988 \mathrm{~m}$., kai dar nebuvo gimusi darnios plètros sąvoka, Amsterdame buvo įdiegta $\mathrm{ABC}$ sistema (Beyer 1999; Noirjean 2003). Ji ịpareigoja: A dideles privačias ir valstybines įmones kurtis viešojo transporto linijų mazguose, B - kitokias įmones - išilgai viešojo transporto linijų, tankinant jų koridorių užstatymą, C - turinčias didelę krovinių apyvartą prie automobilių kelių ir gatvių. Tai ne vieninteliai reguliavimo svertai. Igyvendintų priemonių efektyvumą galime aiškiai matyti iš vienos svarbiausių sisteminių 
pasekmių - mobilumo pagal dažniausiai naudojamų susisiekimo būdų pasiskirstymų palyginimo:

\begin{tabular}{lccccc}
\hline & P + Dv & VT & LA & taksi + kita & \\
\hline $\begin{array}{l}\text { Amsterdamas, } \\
2000\end{array}$ & 46 & 23 & 31 & & fproc. \\
\hline Vilnius, 1993 & -18 & +29 & -14 & +1 & $\begin{array}{c}\text { fproc. } \\
\text { punktai }\end{array}$ \\
\hline Atènai, 1999 & -32 & +9 & +29 & +6 & \\
\hline Vilnius, 2004 & -37 & -3 & +40 & +1 & \\
\hline
\end{tabular}

Šaltiniai: Vannina 2000, Juškevičius, Valeika 2007

Paaiškinimai:

$P$ - pèsčiomis, Dv - dviračiu, VT - visuomeniniu transportu, LA - lengvuoju automobiliu

Nesunku suprasti, kokie reikšmingi ekonominès, finansinès, socialinès, taršos ir kitų pasekmių skirtumai slypi tarp 46 ir 9 proc. kelionių pèsčiomis ir dviračiu, 31 ir 71 proc. kelionių lengvaisiais automobiliais dydžių Amsterdame ir Vilniuje. Palyginimas Vilniaus nenaudai dar ir dèl to, kad situacija blogeja. Tai nèra netikètumas, nes miestas kaip metropolis neturi urbanistinès politikos, išskyrus kai kuriuos darniosios plètros elementus, deklaruotus miesto BP, tačiau neigyvendintus dèl krizès, finansinių išteklių, vystymo valdymo problemų. Viešojoje spaudoje (žurnale „Veidas“, 201006 28) rašoma, kad Lietuvoje yra daugiau kaip 200 vidutinio ir ilgo laikotarpio strategijų. Miestų ar apskritai urbanistinès strategijos nèra.

Madingo ir oficialiai deklaruojamo darnaus urbanistinio planavimo ir vystymo abècèle - kaip urbanistinès strategijos pagrindai - yra:

a) urbanistinio ir susisiekimo sistemos planavimo integracija. Kaip minèta, tai būtų konsoliduotų bendrụjų planų kompetencija. Integracija turètų apimti visus probleminius susisiekimo aspektus ir organizacines, technines, inžinerines, finansines bei administracines priemones, leidžiančias siekti VT ir pèsčiųjų prioriteto, eismo saugos, mobilumo ir automobilių statymo, laikymo bei eismo valdymo, mažesnès taršos ir t. t. T. y. tos priemonès papildytų miesto struktūros galimybes spręsti minètas problemas. Iš dalies jų elementai veikia, tačiau neefektyviai, netrūksta ir neteisingų atvejų. Pagrindine priežastimi galima laikyti faktą, kad neįvertintas lengvųjų automobilių naudojimo efektas. Jo esmè - masinis naudojimas skatina gyvenamosios funkcijos (iš dalies gamybos) teritorinę sklaidą, o socialinès infrastruktūros - koncentraciją; lengvųjų automobilių naudotojai gatvių tinkle gali laisvai rinktis neformalias asmeniškai efektyviausias kelionių trasas, o jų visuma sukuria problemines erdves. Visa tai susisiekimo sistemos projekto (SSP) objektas. SSP būtų bendrųjų planų sudedamoji dalis. Jo sprendiniai, priešingai nei BP, būtų privalomi, o rengimo dažnį lemtų miesto vystymo tempas ir problemų mastas arba $5 \mathrm{~m}$. standartas. Taip tęstinio planavimo atveju SSP taptų kokybès garantu ir indikatoriumi;

b) susisiekimo tinklo efektyvumo požymiai:funkciškai mišrios, socialiai integruotos teritorijos, palankios viešosioms erdvems kurti ir susisiekti pésčiomis, jose nenutrūkstamumo principu formuojamas užstatymas yra palankus socialinei integracijai ir viešajam transportuifunkcionuoti. Taigi, pirma, šis darnios plettros principas reikalauja pagrịsti gyvenamųjų struktūrinių vienetų užstatymo tankio, intensyvumo ir būstų tipo iqvairoves bei tikètino gyventojų ir darbo vietu tankio slenksčius. Stambių kompleksų (hipercentrų ir kt.) sklaidos racionalumas matuojamas susisiekimo su jais viešuoju transportu ir pesčiomis struktūrinès dalies dydžiu. Antra, jis visiškai atmeta standartizuotų žemés paskirčių, būdų ir pobūdžių dogmą. Trečia, intensyviausiai užstatytų teritorijų konfigūracija ir apskritai miesto forma turi koreliuoti su viešojo transporto tipu ir jo pasiekiamumo zona;

c) miesto centriniu funkciju perskirstymas. Tai prielaida kurti policentrinès, decentralizuotos koncentracijos, archipelagų tipo urbanistines struktūras kaip alternatyvas miesto išskydimui, chaotiškam užstatymui;

d) urbanistiniu sistemu funkcionavimo ir ju struktūru valdymas. Jeigu valdymo priemone būtų pasirinkta automobilių naudojimo politika, pagal Boillat (Boillat 2008) ją galima būtų naudoti mažiausiai trims tikslų grupèms. Jeigu didinamos automobilių saugojimo vietų skaičiaus galimybès - stipreja kvartalo gyvybingumas, patrauklumas įmonèms ir lankytojams; galimybès mažinamos - mažèja lengvųjų automobilių eismo intensyvumas, dideja viešojo transporto patrauklumas, gereja gyvenamosios aplinkos kokybè, reali netinkamų įmonių išsikèlimo tikimybė; automobilių mokamas saugojimas galimybè sukaupti lèšu viešajam transportui vystyti; 
e) kompleksinis ir tarpdisciplinis urbanistinio planavimo supratimas. Planavimas remiasi ịvairių mokslo sričių - urbanistikos, architektūros, ekonomikos, sociologijos, matematikos, teisès, geografijos - ir kt. žinių deriniu. Atrodytų, kad tai nereikalauja ypatingo pagrindimo, tai savaime suprantamas ir pripažįstamas principas (Noirjean 2003; Equipe... 2009). Lietuvoje atvirkščiai - proteguojami vien architektai, nors urbanistinio planavimo kontekste meno aspektų šiuolaikiniu supratimu nepakanka.

Racionalaus miesto vystymo ir atitinkamos struktūros formavimas yra ilgalaikis procesas, kuriame realiai dèl finansinių, organizacinių, investicijų neapibrèžtumo, gyventojų mokumo ir kitų priežasčių gali atsirasti nesuderintų miesto plètros veiksmų, neigyvendintų sprendinių, igyvendinimas gali būti atsilikęs.

Viena iš aktualiausių miesto darnaus vystymo problemų - miestų centrų veiklos aktyvumo mažèjimas. Iš dalies tai objektyvus procesas. Pirma, susijęs su gyvenamosios aplinkos kokybès ir būsto tipo bei jo vietos laisvu pasirinkimu, kurio prielaidos yra automobilizacija, rinkos ekonomikos raida, socialinių santykių kaita. Antra, susijęs su suburbanizacijos ciklu. Vakarų Europoje tai seniau žinoma problema, kurios sprendimas siejamas su viso miesto regeneracija arba su veiksmais, kurie gražintų vidurinę gyventojų klasę i senamiesti (pavyzdžiui, Ananian 2009; Programme... 2004; Galivel... 1999). Lietuvoje tai priklausys nuo senamiesčių kaip saugomų teritorijų vystymo strategijų. Jeigu jos atmestų tokị tikslą, gali susiformuoti „riestainio tipo" miestai dèl priemiesčių vystymosi, o viduryje gali likti pustuštės istorinės miesto dalys ir pilni prekybos centrai. Problema ta, kad vien laisva rinka negali pateikti sprendimo (Lorens 2006). Todèl urbanistinių sprendinių igyvendinimo ịstatyme turètų atsirasti prievole rengti miesto regeneracijos projektą. Tai dokumentas, kuris sistemiškai apimtų miesto centro rekvalifikaciją, aikščių rehabilitaciją, infrastruktūrų modernizavimą, būstų renovaciją, funkcinès mutacijos reiškinius ir kitus dalykus, taip pat naujos statybos iterpimą ir t. t.

Dar vienas svarbus sprendinių igyvendinimo aspektas - savivaldybès dešimtmečiui ar ilgesniam laikotarpiui paprastai neranda būdų rezervuoti komunikacinius koridorius, teritorijas kitoms bendroms miesto reikmėms. Todèl nèra jokios garantijos, kad galima išvengti urbanistinių deformacijų. Rezervavimą komplikuoja ir tai, kad savivaldybè nedisponuoja miesto žeme, finansiniais miesto tolygaus vystymo resursais, neturi savarankiškų ekonominių ir kitokių svertų reguliuoti miesto urbanistinį vystymą erdveje bei laike, lieka neišspręsta viešųjų ir privačių interesų problema. Savivaldybè savarankiškai negali išspręsti tokio tipo problemų. Tai siūlomo įstatymo kompetencija.

\section{Išvados}

Urbanistinès deformacijos yra masinis reiškinys. Svarbiausia priežastis yra atotrūkis tarp palyginti laisvo ir finansiniais, žemès bei kitais resursais nevaržomo bendrojo planavimo ir neapibrèžtų galimybių igyvendinti bendrojo planavimo sprendinius. Todèl visi bendrieji planai, kurie tvirtinami $10 \mathrm{~m}$. laikotarpiui de facto, yra neapibrèžto laikotarpio vizijos.

Planavimo sistemos ideologija nuo gyvenimo atsilieka dešimtmečiais, ji nekoreliuoja su esminemis šiuolaikinių urbanistinių procesų sukuriamomis problemomis, neskatina jų pažinti, yra uždara ir subjektyvi, neskatina ir negali ịvertinti planavimo kokybès, tačiau atvira subjektyvumui, savavališkam veikimui menkai atsižvelgiant ị kitų nuomonę, galimybes bei objektyvias sąlygas.

Straipsnyje pateiktus pasiūlymus reikia suprasti ne kaip baigtini produktą, bet kaip argumentuotus principus, kurie turètų pakeisti pačios dabar veikiančios planavimo sistemos deformacijas ir taip ją modernizuoti.

Pokyčiai planavimo sistemoje priklausys nuo to, ar atsiras kritinè masè žmonių, galinčių lemti efektyvią sistemos vystymo krypti. Kol kas ta mase ir jos efektyvumas yra maži. Pakeisti situaciją labai sunku, nes veikia labiau skaldantys privatūs ir atskirų veiklos sričių interesai (garantuota rinka, itakingumas, užimtumas, pelnas ir kt.) negu bendrų visuomenès interesų labui konsoliduojantys veiksniai. Planuotojai taip pat nèra vieningi, jų ideologinè bazè labai skirtinga.

Vidiniai ir išoriniai planavimo ir igyvendinimo sistemos prieštaravimai egzistuos visada. Tačiau turètų sumažèti kompetencijų skirtumai, atsirasti gebẻjimas suprasti urbanistinių procesų sudètingumą, kilmę, raidą, pasekmes ir jų reikšmę šalies vystymuisi. Svarbiausias vaidmuo sprendžiant šias problemas turètų tekti urbanistikos mokslo ir praktikos žmonems, kurių veikla apima daugybę sričiu ir kuriems būdingas sisteminis mąstymas, atitinkamai sumažinant valdininkų kaip ekspertų vaidmenị. Pagrindinè priemonè švietimas, kuris įvairiomis formomis net ir privalomai turètų pasiekti visų rangų politikus, valdininkus, planuotojus. Gyventojams turetų būti prieinami iliustratyvūs normų ir kitokių reikalavimų paaiškinimai. Ypač reikalingi planavimo teisès aktų komentarai, kurie leistų suprasti ir atskirti, kada baigiasi asmenine valdininko nuomonè ir kur prasideda oficiali valstybès, ministerijos pozicija. 


\section{Literatūra}

Ananian, P. 2009. Habitat, centralites et regeneration urbaine a Bruxelles [interaktyvus] [žiūrèta 201003 05]. Prieiga per internetą: <http://www.urba.ucl.ac.be/hd/ revitalisationcentresville.html>.

Beyer, J. C. 1999. Amsterdam, le plus petite des grandes metropoles. L'Hartmattan.

Boillat, P. 2008. Les politiques de stationnement: un outil de maîtrise de la mobilité [interaktyvus] [žiūrèta 201007 21]. Prieiga per internetą: <http://www.unige.ch/ses/geo/ oum/doc/Les\%20politiques\%20de\%20stationnement_30_04_2008.pdf>.

Darnioji pletra teritoriju planavime ir urbanistikoje. 2008. Lietuvos Respublikos Vyriausybès Ministro Pirmininko $2008 \mathrm{~m}$. sausio 8 d. potvarkiu Nr. 7 sudarytos darbo grupès pasiūlymai, kiti veiklos rezultatai. Vilnius: Petro ofsetas. $107 \mathrm{p}$.

De Brest metropole oceane. Communaute urbaine. Plan local d'urbanisme [interaktyvus] [žiūrèta 200806 01]. Prieiga per internetą: $<$ http://applications-internet.brest-metropole-oceane.fr./VIPDU72/plu/reglement/PLU-brestmetropole-oceane.pdf $>$.

Edinburgh City Local Plan. 2007. Approved by The City of Edinburgh Council, 22 March. ISBN 185191075 1. 175 p.

Equipe de researche urbanisme et management (UMR PACTE 5194) [interaktyvus] [žiūrèta 200910 07]. Prieiga per internetą: <http://www.iug-grenoble.fr/recherche/presentation.htm>.

Galivel \& Associés. 1999. Regeneration urbain et habitat: moteur de l'economie et de l'emploi a Montelimar [interaktyvus] [žiūrèta 201003 08]. Prieiga per internetą: $<$ www.Constructa-promotion.com/dossierdepresse/news/ news_FR_19.pdf $>$.

Harvey, J. 1992. Urban land economics. Third Edition. MACMILLAN, p. 437.

Juškevičius, P.; Jauneikaitè, K. 2008. Urbanistinių struktūru formavimo ir žemès naudojimo klasifikavimo problematika, Urbanistika ir architektūra 32(4): 240-247.

Juškevičius, P.; Valeika, V. 2007. Lietuvos miestu sistemu raida: monografija. Vilnius: Baltijos kopija. 240 p.

Lemaitre, E. 2007. Quelques exemples de maitrise de l'etalement urbain en France (Lettre Evaluation $n 11$ juin 2007) [interaktyvus] [žiūrèta 201002 23]. Prieiga per internetą: $<$ http://www.ecologie.gouv.fr/Quelquesexemples-de-l.html>.

Lietuvos Respublikos aplinkos ministro 2006 m. gruodžio 14 d. įsakymu Nr. D1-591 patvirtintos Miestų ir miesteliu teritoriju bendruju planu rengimo taisykles.

Lietuvos Respublikos teritoriju planavimo i̇statymas, patvirtintas $2004 \mathrm{~m}$. sausio $15 \mathrm{~d}$. potvarkiu Nr. IX-1962, ir vèlesni ìstatymo straipsnių papildymo ir pakeitimo įstatymai.

Lorens, P. 2006. Trends and Problems of Contemporary Urbanization Processes in Poland. Urban and regional planning and development series: Spatial planning and urban development in thenew EU member states. Ashgate publishing company, 95-112.

Noirjean, S. 2003. Mobilité et de planification urbaine: la méthode $A B C$ dans l'ouest lausannois face aux besoins de l'économie [interaktyvus] [žiūrèta 201007 21]. Prieiga per internetą: <http://www.unil.ch/webdav/site/ouvdd/shared/Colloque\%202005/Communica tion/C)\%20Mise\%20 en\%20oeuvre/C5/S.\%20Noirjean.pdf $>$.

O'Sullivan. 2002. Urban Economics. Fourt Edition. Department of Economics, Oregon State University. Irwin McGraw-Hill (leidimas rusu kalba, Maskva, INFRA-M, 2002).

Pęski, W. 1999. Zarządzanie zrownowažonym rozwojem miast. Warszawa: „Arkady“.

Programme d'Actions Prioritaires Centre D'Activites Regionales Split. 2004. Lignes directrices pour une regeneration urbaine dans la region Mediterraneenne [interaktyvus] [žiūrèta 201003 06]. Prieiga per internetą: <www. pap-thecoastcentre.org/french/ Regeneration\%20urbaine. pdf $>$.

Rockingham County Land Use Plan [interaktyvus] [žiūrèta 200806 03]. Prieiga per internetą: <http://www. co.rockingham.nc.us/Planning/exsumfin.pdf $>$.

Regulski, J. 1982. Ekonomika miasta. Wyd. 1. Warszawa. Panstwowe Wydawnictwo Ekonomiczne.

Srèbalius, T. 2010. Naujadaras: sportine fantastika, Statyba ir architektūra 2010/02-03: 4-7.

Stirling Local Plan. 2006 [interaktyvus] [žiūrèta 200806 03]. Prieiga per internetą: <http://www.stirling.gov.uk/index/ services/planning/localplan/lp-1st-alteration/towns_ and_villages-3.htm>.

Two Rocks local planning scheme [interaktyvus] [žiūrèta 2008 $1026]$. Prieiga per internetą: <http://www.wapc.wa.gov. $\mathrm{au} /$ Region+schemes/Metropolitan+Region+Scheme/25+0 $00+$ Series/default.asp $\mathrm{x}>$.

Vannina, P. Politiques urbaines et mobilite durable: analyse comparee d'Athenes et Amsterdam [interaktyvus] [žiūrèta 201007 21]. Prieiga per internetą: <http://www.ecologieet-politique.info/IMG/pdf/29_Politiques_urbaines_et_ mobilite_durable.pdf $>$.

\section{DEFORMATIONS OF URBAN PLANNING}

\section{P. Juškevičius, K. Gaučè}

Abstract. As deformations in urbanism is a massive phenomenon, the aim of the paper authors is to point out crucial deformations, experienced in municipal territory planning, which mutilate the meaning of comprehensive planning. Any deviations (distortions) from anything that is normal, logical, systematic, objective and reasoned economically, socially, etc. are understood as urban planning deformations and factors encouraging these deformations are the main object of this paper. These deformations affect the implementation success of comprehensive planning solutions and in general have an influence on the quality of urban planning. The quality of planning should be the most important concern, but the evaluation of planning quality is complicated, that's why the authors suggest an idea of comparative evaluation and reasoned principles which should change deformations in existing planning system and in this way modernize it.

Keywords: law of territory planning, deformations in urbanism, comprehensive planning, evaluation of planning quality. 


\section{PRANCIŠKUS JUŠKEVIČIUS}

Dr Habil, Prof., Dept of Urban Design, Vilnius Gediminas Technical University (VGTU), Pylimo g. 26/Traku g. 1, 01132 Vilnius, Lithuania.E-mail: pjuskevicius@gmail.com

Publications: author of over 70 research papers, author or co-author of 5 monographs. Projects: project manager or coauthor of some town master plans, land-use projects, transport feasibility studies. Research interests: urbanism, urban morphology, public transport, mobility.

\section{KRISTINA GAUČE்}

Head of Territory Planning Department, JSC "Statybos strategija“, Smolensko g. 10, 03201 Vilnius, Lithuania.

E-mail:kristina@s-strategija.lt.

Dr, Assoc. Prof., Dept of Urban Engineering, Vilnius Gediminas Technical University (VGTU), Sauletekio al. 11, 10223 Vilnius, Lithuania.E-mail: kristina.gauce@vgtu.lt.

Publications: author or co-author of 10 research papers. Projects: project leader or co-author of various land-use planning projects. Research interests: mobility management, integration of mobility planning into land-use planning process. 